\title{
How a Traditional Homemaker Predicts: An Ethnographic Study
}

\author{
Vici Suciawati, Mohamad Gilar Jatisunda*, \& Nia Kania \\ Department of Mathematics Education, Universitas Majalengka, Indonesia, 45411 \\ *Corresponding author: g.jatisunda@unma.ac.id | Phone Number: +628122240180
}

\section{ARTICLE HISTORY}

Received: 08 October 2020

Revised: 13 March 2021

Accepted: 26 April 2021

\section{KEYWORDS}

Intuition;

Ethnomathematics;

Ethnography;

\begin{abstract}
Intuition is the first way humans get knowledge. A worker in making a traditional West Java house works using his experience to be able to determine how many building materials are needed to become a house. The roof of the house is one part that is quite complicated to determine the amount of wood needed. Workers using intuition based on experience that has been experienced greatly determine the accuracy of the measure. Through this research, the researcher hopes that the method of determining the amount of wood used to make the roof (suhunan) of houses in West Java has added scientific value because it is related to existing mathematical concepts. The subjects of this study were workers who made traditional houses in West Java Regency. This study uses a qualitative method with an ethnographic approach. This study aims to describe an in-depth study of how to determine the amount of wood used to make traditional houses and its relation to mathematical concepts. The results showed that the workers who made the traditional houses started outing for the first time by calculating the number of wood chips needed to make the KAP intact to make the roof from it, they were easier to determine the amount of wood needed.
\end{abstract}

This is an open access article under the CC-BY-SA license.

\section{INTRODUCTION}

Science arises because of problems in everyday life and is a product of intuition (Morris, 2014). When talking about everyday life, it cannot be separated from culture. In general, the notion of culture is a system of thinking about human values, morals, norms, and beliefs (Pardimin, 2018). A culture is identified based on a system of explanations from philosophies, theories, and everyday behaviour (D Ambrósio, 2005). If we look at this, is there a possible intersection between mathematics and culture? The culture of mathematics is the aspect of mathematics related to scientific disciplines such as individual attitudes towards beauty, accuracy, structure, etc. (Burton, 2009). Mathematics is culture-free, but context is not (Davison, 2007). The culture affects the way people understand something, for example, understanding mathematical concepts, for example, geometric axioms (Fasheh, 1997). Then a growing literature deals with the relationship between culture and mathematics and describes examples of mathematics in cultural contexts (Barton, 1996).

Anthropologists point out that mathematical practices, such as counting, sorting, measuring, and weighing, are carried out in a very different way than is usually taught in the school system, which has led to several studies of the evolution of mathematical concepts within cultural and anthropological frameworks (D'Ambrosio, 1985). The object of study between mathematics and culture appears, which is commonly called ethnomathematics. Apart from generating new mathematical thinking, ethnomathematics has fostered authentic dialogue between artists of various kinds and mathematicians (Barton, 2008). The notion of ethnomathematics itself is the art of explaining, understanding the socio-cultural and natural environment. The dynamics of these interactions are mediated by communication and symbolization, which then produces structured knowledge, which eventually becomes a scientific discipline (Barton, 1996). Although ethnomathematics seems popular as a theoretical concept, it is still not well defined, and this is because two different pieces of literature examine culture and mathematics, namely Anthropology and Mathematics (Wahyudin, 2018). Nevertheless, apart from this opinion, Ubiratan d'Ambrosio has defined ethnomathematics as the cultural anthropology of mathematics and mathematics where D'Ambrosio started the formulation in 1977 by starting with ethnoscience theory with the expansion of technological phenomena that are directly related to their social, economic, and cultural backgrounds (Gerdes, 1994).

Ethnomathematics research has been widely conducted in Indonesia and focuses on mathematical contexts that exist in society. Exploration, documentation, literature study, and observation in the Muaro Jambi temple environment, the findings found that there is a quadrilateral concept of a flat shape in several Muaro Jambi temple structures. (Hardiarti, 2017). The exploration of determining the best day is based on mathematical concepts used by the Cigugur indigenous people by using the concept of addition and the concept of comparison (Umbara et al., 2019). An exploration of ornamental patterns that contain geometric elements, making them culturally meaningful patterns created through geometric transformations (Pratama et al., 2019). Exploring mathematical ideas that arise in weaving activities such as 
counting, determining the location of objects, measuring, designing, explaining, comparing, classifying, using implication logic, palindromic numbers, and various geometric concepts. (Dominikus et al., 2017). Ethnomathematics is still widely used by Sundanese people, especially in rural areas, with measurement units, mathematical modelling, and the hour symbol. (Abdullah, 2017). The Cipatujah people have used mathematics in their life, including how to determine the time to go to the sea for fishing and how they build houses (Kusuma et al., 2016). Ethnomathematics exploration in Sundanese society is estimating, measuring, and making patterns that appear in daily activities such as "kibik" (a unit for measuring volume), "bata" (a unit for measuring surface area), and paths "Pihuntuan" (model stick work) (Muhtadi, 2017).

Other ethnomathematics research in Indonesia is related to the learning process. One of them is the possibility of ethnomathematics to embrace the curriculum and have a relatively similar role in formal mathematics, namely; (1) substitute for school mathematics; (2) providing school mathematics; (3) achievement in school mathematics: (4) motivation for school mathematics and (5) as local content in school mathematics and schemes for developing student character (Budiarto et al., 2019). The exploration of batik motifs (Slopes, Sepilok, and Jlamprang) can be used in mathematics learning in schools by studying the mathematical concepts of lines, angles, triangles, rectangles, and circles (Pramudita \& Rosnawati, 2019). Research with the object of ethnomathematics ic studies is proliferating with much exploration of the context of mathematics in culture in Indonesia and several studies implemented in the mathematics learning process in schools.

In this study, the focus is on assessing the thought processes of the Sundanese people when they carry out mathematical activities starting from the philosophical view that mathematics is logicism, intuitionism, and formalism (Wilder, 1967). Human thought processes when doing mathematics are exposed to intuitive cognitive strategies, based on experience, while others are formal cognitive, rule-based, or analytical (Norenzayan et al., 2002). Intuitionism is a philosophy that assumes that humans get knowledge and truth through intuition (Fischbein, 1987). Intuition goes on making use of special knowledge in the form of expertise accumulated from past processes (Sinclair, 2010). According to Jung's theory of intuition, every individual has intuition but to different degrees and is manifested in personality types (Jatisunda \& Nahdi, 2019). Descartes states intuition as the highest form of knowledge through which the essence of everything can be revealed (Lerman, 2014). Then intuition is the ability to draw conclusions and solve problems effectively, even when lacking information (Karwowski, 2008). The phenomenon of intuition involves an emotional process, fast and unconscious (Lufityanto et al., 2016). When linked with mathematics, intuition, together with insight, is one way mathematicians understand epistemological practice through which they get to know mathematics more deeply (Burton, 2009). The role of intuition in mathematical activities of people with various cultural backgrounds that influence it is interesting to study.

In building a house, humans need to calculate, measure, and draw house designs and estimate the building materials needed to make the house. In commerce, humans use calculations to determine the number of goods sold, the amount of capital, and the profit or loss experienced. Likewise, the development of modern technology that is happening also does not escape the role of mathematics. Mathematical phenomena occur in many human activities that are unconsciously part of mathematics (Sembiring, 2010; Sembiring et al., 2008). Mathematics is very close to culture in the context of behaviour or habits that have existed since ancient times and are carried out from generation to generation (Muhtadi, 2017). The phenomenon of a traditional house maker will be interesting to be material for study because when they work in building houses, they are involved in many mathematical activities, and of course, they also work a lot with their intuition and experience when making houses.

Measurement, carried out carefully, is one of the scientific processes (Pandiangan, 2014). Intuition is one of the tools used in various functions in everyday life and is mainly used as a decision-making tool (Goldberg, 1989). In particular, some experiences can be a tool to verify intuition, namely that there are not only intellectual dimensions but also sensory and emotional dimensions. (Petitmengin-Peugeot, 1999). Intuition goes hand in hand with the idea that intuition can be learned, without excluding the possibility that the source of intuition is innate. The cognitive view implies that intuition can be trained and expanded (Agor, 1989). So that the process of a traditional house maker when they measure the amount of wood needed to make a house, is a scientific process and also does not depend on their intellectuals in the field of mathematics but there is a sensory experience that is inherent in their minds, namely intuition.

\section{RESEARCH METHOD}

The method used in this study is qualitative. Qualitative research methods are more based on phenomenological characteristics that prioritize appreciation (Gunawan, 2013). Qualitative research is a form of social action that emphasizes the way people interpret and understand their experiences to understand individual social realities (Mohajan, 2018). It is described as a useful model that occurs in a natural environment and allows the researcher to develop every detail of its actual high-involvement experience (Creswel, 2009). The research design used was ethnography. Ethnographic design is a research procedure that functions to describe, analyze, and interpret culture from time to time by studying patterns of behaviour, beliefs, and the language they use together that occur in a community (Creswell, 2012), by involving an in-depth study of cultural identity based on the perspective of the researcher (etic) and the perspective of research participants (emic) (Gall et al., 2014). Ethnographic design is used because ethnomathematics research examines the relationship of certain cultures to mathematical concepts that exist in that cultural context (Prahmana, 2020). This study used an ethnographic design by describing a mathematical object study in determining the amount of wood needed to build a roof in the Sundanese community. All research data were obtained based on field observations, literature study, documentation, and interviews. The interview was conducted directly with Father Jumhari from Cisoka Village, Cikijing District, Majalengka Regency, to discuss how to predict the amount of wood needed to make house roofs in West Java terms the roofs of the West Java version. He is one of the elders in Cisoka Village who can understand how to make roofs with more than 40 years of experience, so this ability is needed to clarify and define specific terms found in the literature study in this study. 


\section{RESULTS AND DISCUSSION}

The natural conditions of West Java, which are mountainous with a narrow coastal plain in the southern part, have educated its people to make careful use of nature, that is, to use it non-destructively is reflected in the pikukuh (guidance/advice of the ancestors) of the Sundanese traditional society: gunung teu meunang dilebur, lebak teu beunang diruksak, larangan teu meunang dirempak, buyut teu meunang dirobah, lojor teu meunang dipotong, pondok teu meunang disambung, nu lain kudu dilainkeun, nu ulah kudu diulahkeun, nu enya kudu dienyakeun. The basic concept of traditional Sundanese architectural design is one with nature (Saputra \& Satwikasari, 2019). The Sundanese people believe that harmony occurs when nature and humans unite, that humans (microcosm) are part of nature (macrocosm), so that synergy must be created between the two. The home concept means that nature is a potential or strength that should be respected and utilized appropriately in everyday life.

This study aims to explore the thinking process of traditional builders (bass) when predicting the amount of wood needed to make house roofs in West Java, with the dominance of the Sundanese ethnic community. For more details on the exploration results regarding the builder's thought process, we first explore the measurements used in making the roof of the house. We explored how to measure the land to make a house. Sundanese people have some to measure the area of location is typically measured using a variety of tools to measure, commonly used ropes. The size used by traditional builders using the units used is bata, or some call it tumbak (bata=tumbak=equal to 14 meters squared). The results of the exploration are the same as those obtained in Cipatujah, a place in the south of West Java, namely the symbolic measuring tools for broad bata or tumbak (Abdullah, 2017; Aini, 2018; Handayani, 2019; Ilham \& Sofyan, 2012; Muhtadi, 2017). One of the findings to measure the length of the participants was the measurement used depa, cengkal, and elo. Depa equal to 1 meter (Abdullah, 2017), ceungkal (equal to 3,75 meter), and elo (equal to 0,68 meter) (Muhtadi,2017). The area size and length measurement are used to determine the area used to make the house.

The next exploration is symbolic of measuring the angle according to the Sundanese people: Nyukon, a broad-angle equivalent to a right angle, or 90 degrees. However, found elsewhere, his name is Masekon (Abdullah, 2017). Masagi, the origin of the word from Pasagi, is described in physical form resembling a rectangular shape. The philosophy of Sundanese life Masagi has the meaning of a person who has united all his different experiences and knowledge that he has experienced in unity. Masagi is a term that describes the condition of a building, each consisting of right angles or squares or rectangles, applied when building a house, to make it more robust (Abdullah, 2017). Determining a form of masagi for traditional house makers in West Java determines it with two events, known as ngawindu. Ngawindu is the process of determining each angle of $90^{\circ}$ by drawing a diagonal line using a rope from each corner. Another way is to use triple Pythagoras with numbers commonly used as $60 \mathrm{~cm}, 80 \mathrm{~cm}$, and $100 \mathrm{~cm}$, but for the size of the land to make a rather large house using the phytagorean triple, there is often an error, that is, sometimes not the shape you get.

The roofs of traditional houses in West Java are quite diverse, but they are almost the same in construction. The traditional Sundanese house has different names depending on the shape of the roof and the door. There are three types of suhunan, namely the long suhunan (bapang), the short suhunan (jure), and the lisung nangkub (the closed mortar). Based on interviews with participants, we asked about the shape of the roof of the house for the first time they made. Participants make the first roof of the house in the form of a Bapang. Most of the houses in West Java are currently in the form of Bapang and Jure. The shape of the roof of the Bapang is like an isosceles triangle with different sides, as rain or heat protection. Types of tools or tools found on the roof of the house:

$\begin{array}{ll}\text { 1. } & \text { Darurung, } \\ \text { 2. } & \text { Kuda-kuda, } \\ \text { 3. } & \text { Pangheret } \\ \text { 4. } & \text { Pamikul } \\ \text { 5. } & \text { Adeg } \\ \text { 6. } & \text { Siku-siku } \\ \text { 7. } & \text { Siku silang } \\ \text { 8. } & \text { Dugdeg } \\ \text { 9. } & \text { Tilam adeg } \\ \text { 10. } & \text { Jambatan } \\ \text { 11. } & \text { Suhunan } \\ \text { 12. } & \text { Lambir } \\ \text { 13. } & \text { Layes } \\ \text { 14. } & \text { Reng }\end{array}$

When making suhunan, usually, the wood needed is based on the names mentioned above. The need for wooden beams depends on the wishes of the homeowner. Before how the house makers calculate the amount of wood, researchers try to find information on how they determine a wooden kibik. Below are interviews with respondents:

Researcher: What is the actual measuring instrument used for measuring?.

Respondent: Kibik is used to measure the volume of wood, for example, the wood used to make poles, usually the size of wood that has been cut (meaning: wooden blocks) $10 \mathrm{~cm} \times 10 \mathrm{~cm} \mathrm{x} 3 \mathrm{~m}$.

Researcher: Please explain the meaning of your explanation, the size of $10 \mathrm{~cm} \times 10 \mathrm{~cm} \times 3 \mathrm{~m}$ ?

Respondent: (Sketching wooden blocks on paper) look at this picture $10 \mathrm{~cm}, 10 \mathrm{~cm}$ there (Shows the height of $10 \mathrm{~cm}$, width $10 \mathrm{~cm}$, and 3 meters is the length of the wood).

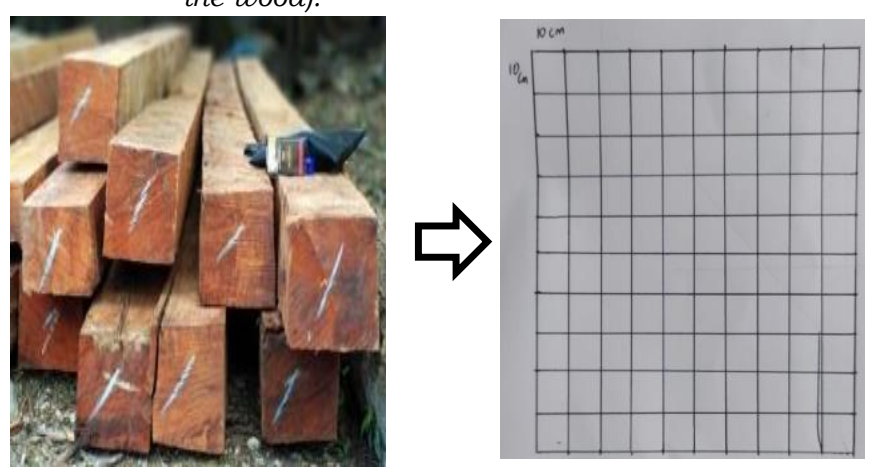

Figure 1. Illustration for Determining Cubic

Respondent: To determine one block of wood, I usually imagine that by stacking the logs, the size of $10 \mathrm{~cm}$ x $10 \mathrm{~cm} \times 3 \mathrm{~m}$ logs ares stacked on top of 10 piles, and ten lined up to the right, as shown. So, to determine one Kubik. 
Respondent: To determine one Kubik by imagining a wooden block measuring $10 \mathrm{~cm} \times 10 \mathrm{~cm} \times 3 \mathrm{~m}$ stretched $100 \mathrm{~m} 3$. Alternatively, at best like this $3 \mathrm{x} \ldots=100$ $\mathrm{m}^{3}$, meaning that it takes 33 logs plus one Galang wood with a size of $5 \mathrm{~cm} \times 10 \mathrm{~cm} \times 3 \mathrm{~m}$ to determine precisely one Kubik.

Researcher: Thank you for the explanation, now how do you determine the number of logs needed to make a suhunan or roof.

Respondent: I tried to make a sketch.

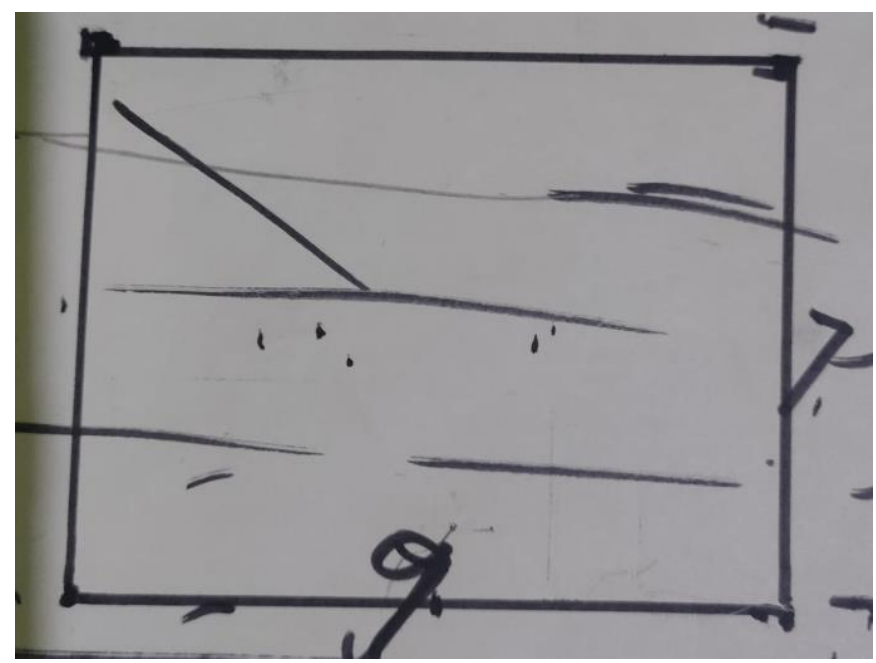

Figure 2. House Land Illustration

Suppose this is the land that will be used to build a house with a size of $9 \mathrm{~m} \times 7 \mathrm{~m}$. First, we usually determine the amount (hood).

Researcher: what is kap ?

Respondent: The kap is a complete roof frame that has a triangular shape like this is an illustration.

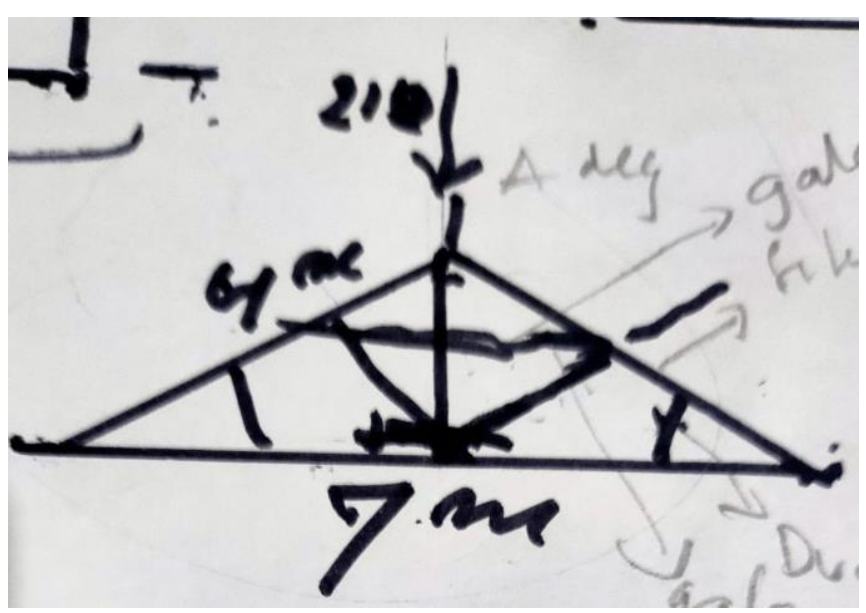

Figure 3. Kap Illustration

If the house is 9 meters long, we usually make four triangles like that, because usually for every 3 meters there is one Kap. Researcher: How to count the number of kibik for one Kap?

Respondent: Because the width is 7 meters, so we need

1) Darurung with a length of $7 \mathrm{~m}^{3}$ with two horses with a length of $4 \mathrm{~m}^{3}$

2) Then determine the length of the adeg, using the 7-meter width multiplied by $30 \%$ slope, so the height of the adeg is

\section{$2.10 \mathrm{~m}^{3}$}

3) Then elbows two pieces with a length of $2 \mathrm{~m}^{3}$ each

4) Then Dugdeg two pieces with a length of $1 \mathrm{~m}^{3}$ each and Tilam Adeg with a length of $1 \mathrm{~m} 3$ and finally a $2 \mathrm{~m}^{3}$ Galang.

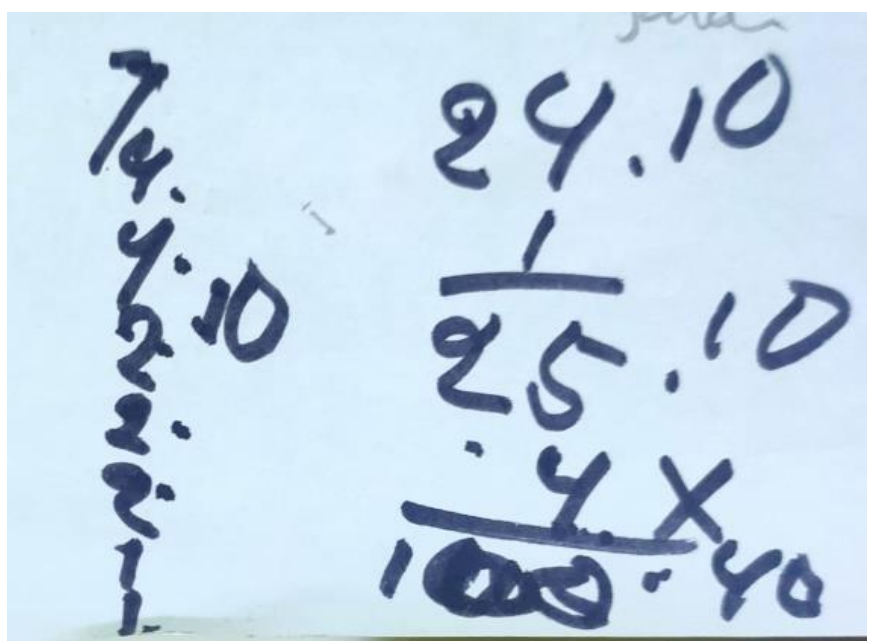

Figure 4. Illustration of adding one Kap

Respondent: So, for one Kap you need $100.40 \mathrm{~m}^{3}$, so for four pieces of hood you need one kibik. We first made the temperature by counting the amount of wood on this Kap. After determining this, it will be easy to determine the amount of wood next. The next Kap requirement is for two $11 \mathrm{~m}^{3}$ of Pamikul, why is it $11 \mathrm{~m}^{3}$ because for Ombar $1 \mathrm{~m}^{3}$ is excess on each side, as well as for two bridges and one piece of temperature with the same length as the Pamikul.

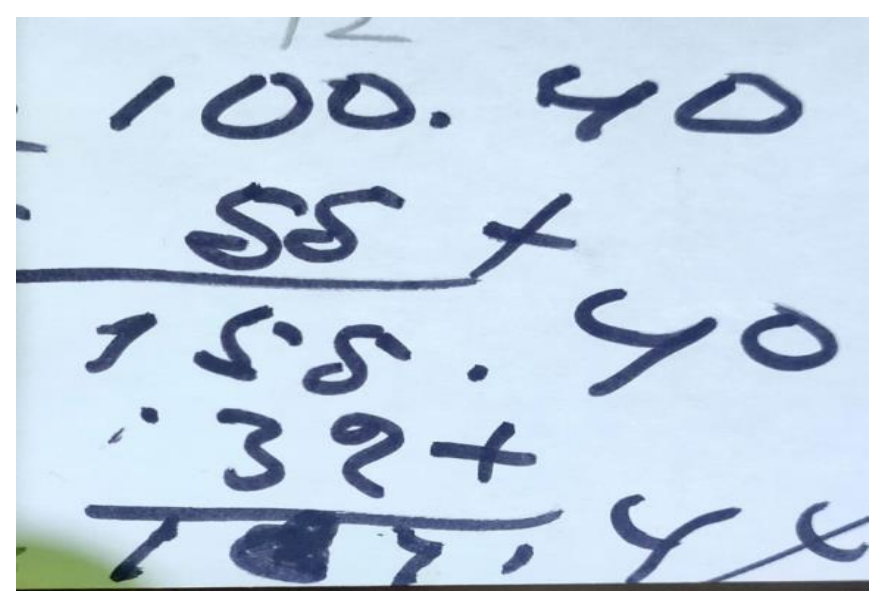

Figure 5. Illustration of respondent calculation

Respondent: So, the total is $187,40 \mathrm{~m}^{3}$, we usually multiply $20 \%$ for the needs if there is a shortage of materials, $187.40 \times 20 \%=37.48 \mathrm{~m}^{3}$, so the total is $224.88 \mathrm{~m}^{3}$. Oh sorry, apparently there is a lack of Siku Silang that have not been counted.

Researcher: How is the Siku Silang?.

Respondent: I will describe it. 


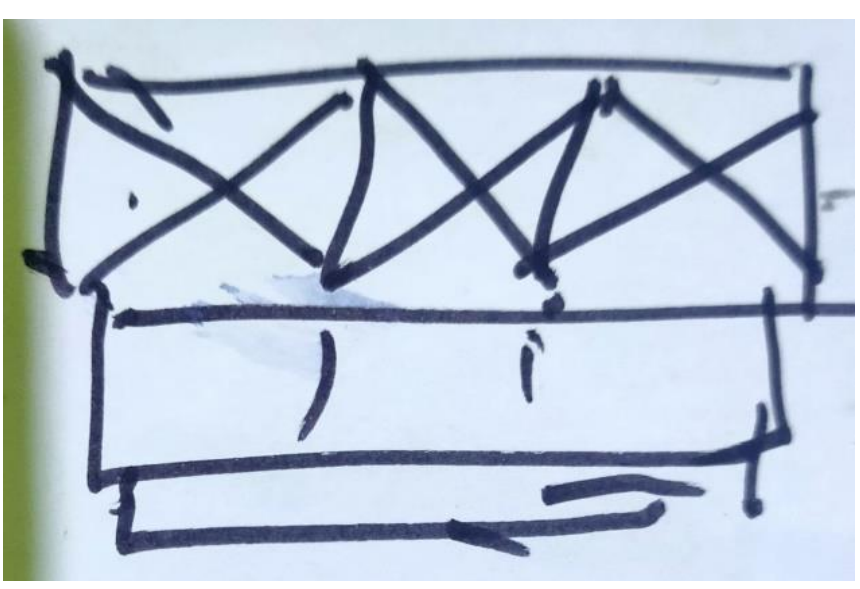

Figure 6. Illustration of Siku Silang

Because there are four Kap, the cross elbows are needed as shown in the picture which serves to strengthen the temperature, as shown in the Figure, it takes $6 \mathrm{~m}^{3}$ of wooden beams. Looks like it should recalculate $187.40+6=193.40$ $\mathrm{m}^{3}$. Then add $20 \%$. So the total is $232.02 \mathrm{~m}^{3}$.

The interview process carried out is an illustration of the way a traditional house maker thinks in determining the amount of wood needed to make a roof. The background of respondents who only go to school at the primary school level learns purely from experience. Many mathematical ideas appear when explaining how to calculate them. The exploration of ethnomathematics in this study uses six dimensions of necessary universal mathematical activities such as: finding, designing, explaining, calculating, measuring, and playing (Bishop, 1988). Moreover, of course, according to the illustration of intuition, what the traditional house maker does will be the same as this illustration.

The following is an illustrative example of a problem faced by Liljedahl that prompted him to understand intuition: a child wants to help put out a fire at Grandpa's house. Before going to his grandfather's house, he had to go to the river to get water first to put out the fire (map of the location of the two houses can be seen in the Figure. below:

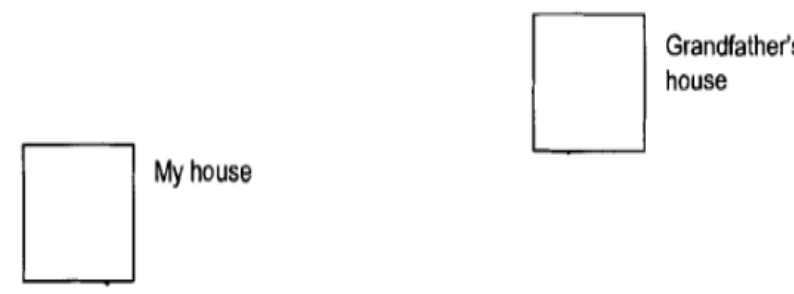

stream

Figure 7. Illustration of intuition

The first step that can be taken is to draw a straight line to a point on the river then proceed to the location of the grandfather's house. Why should it be a straight line? Because the shortest path of two points on a plane is a straight line. How to prove it? The proof is not simple, but we can intuitively accept the statement. In other words, maybe we cannot prove the truth of the statement, but intuitively with a very high level of confidence, we can accept the statement as truth. This is an example of accepting a mathematical statement intuitively.

According to (Jung, 2016), intuition is a psychological function that transmits subconscious perceptions. Intuition is seen as a cognitive function beyond reason, and it provides judgment whenever rational or other cognitive functions do not work. According to Jung's theory of intuition, every individual has intuition but to different degrees and is manifested in the form of personality types. Intuition is one of the thinking activities that is not based on reasoning. Examples of statements that are intuitive include: the shortest distance between two points is called a straight line (the shortest way between two points is the straight line) and the whole is more significant than its parts (the whole is more significant than each of its parts).

\section{CONCLUSION}

In Sundanese culture, each generation is accustomed to using symbolic mathematical calculations that are used in daily activities, concerning the calculation of basic units, length, width, area, height, weight, group, and time. Apart from that, mathematical calculations are also known, to model, predict certain natural phenomena. Ethnomathematics use cases like this are still widely used, especially by rural communities. The illustrates that the Sundanese have good skills in Ethnomathematics, and need to be socialized, used and maintained primarily by formal educators. Apart from giving an idea to the future Sundanese young generation, that Sundanese society is affluent in ethnomathematics and needs to be preserved so that no time is lost. A specific example in this research is how a traditional house maker can predict the amount of wood needed to make a roof with repeated experiences to get the right conclusion to predict.

\section{ACKNOWLEDGEMENTS}

Many thanks to those who supported this research process. Head of the Mathematics Education Study Program, Chair of P3M and Rector of Majalengka University for financial support for this research.

\section{REFERENCES}

Abdullah, A. S. (2017). Ethnomathematics in Perspective of Sundanese Culture. Journal on Mathematics Education, 8(1), 1-16. https://doi.org/10.22342/jme.8.1.3877.1-15.

Agor, W. H. (1989). Intuition in organizations: Leading and managing productively. Sage Publications, Inc.

Aini, I. N. (2018). ETNOMATEMATIKA: Matematika dalam Kehidupan Petani di Kabupaten Karawang. Teorema: Teori Dan Riset Matematika, 2(2), 101-106.

https://jurnal.unigal.ac.id/index.php/teorema/article/downl oad $/ 1072 / 968$

Barton, B. (1996). Making sense of ethnomathematics: Ethnomathematics is making sense. Educational Studies in Mathematics, 31(1-2), 201-233.

https://doi.org/10.1007/BF00143932

Barton, B. (2008). Cultural and social aspects of mathematics education: Responding to Bishop's challenge. In Critical Issues in 
Mathematics Education (pp. 121-133). Springer.

https:// doi.org/10.1007/978-0-387-09673-5

Bishop, A. J. (1988). Mathematics education in its cultural context. Educational Studies in Mathematics, 19(2), 179-191.

https://doi.org/https://doi.org/10.1007/BF00751231

Budiarto, M. T., Artiono, R., \& Setianingsih, R. (2019). Ethnomathematics: Formal Mathematics Milestones for Primary Education. Journal of Physics: Conference Series, 1387(1), 12139. https:// doi.org/10.1088/1742-6596/1387/1/012139

Burton, L. (2009). The culture of mathematics and the mathematical culture. In University science and mathematics education in transition (pp. 157-173). Springer.

https://doi.org/10.1007/978-0-387-09829-6_8

Creswel, J. W. (2009). Research design: Qualitative, quantitative, and mixed methods approaches. Los Angeles: University of Nebraska--Lincoln.

Creswell, J. W. (2012). Educational Research: Planning, Conducting and evaluating Quantitative and Qualitative Research (4th ed). Pearson education, Inc.

D'Ambrosio, U. (1985). Ethnomathematics and its place in the history and pedagogy of mathematics. For the Learning of Mathematics, 5(1), 44-48. http://www.jstor.org/stable/40247876

D Ambrósio, U. (2005). Society, culture, mathematics and its teaching. Educação e Pesquisa, 31(1), 99-120.

https: / www.scielo.br/scielo.php?pid=S1517-9702200500010000 $8 \&$ script $=$ sci_arttext\&tlng $=$ es

Davison, D. M. (2007). In what sense is it true to claim that mathematics is culture-free. Mathematics in a Global Community, 139-143.

http://math.unipa.it/ grim/21_project/21_charlotte_DavisonPa perEdit.pdf

Dominikus, W. S., Nusantara, T., \& Subanji, M. M. (2017). Ethnomathematical ideas in the weaving practice of Adonara Society. Journal of Mathematics and Culture, 11(4), 83-95.

https://adobaladesa.id/wp-content/uploads/2018/12/Final-Eth nomathematical-Ideas-in-the-Weaving.pdf

Fasheh, M. (1997). Mathematics, culture, and authority. Ethnomathematics: Challenging Eurocentrism in Mathematics Education, 273-290.

Fischbein, E. (1987). Intuition in science and mathematics: An educational approach (Vol. 5). Springer Science \& Business Media. https://doi.org/10.1007/0-306-47237-6

Gall, M. D., Gall, J. P., \& Borg, W. R. (2014). Applying educational research: How to read, do, and use research to solve problems of practice. Pearson Higher Ed.

Gerdes, P. (1994). Reflections on ethnomathematics. For the Learning of Mathematics, 14(2), 19-22.

Goldberg, P. (1989). The intuitive experience. Intuition in Organizations: Leading and Managing Productively. Newbury Park, C A: Sage, 173-194.

Gunawan, I. (2013). Metode penelitian kualitatif. Jakarta: Bumi Aksara, 143.

Handayani, S. (2019). Pengaruh Model Pembelajaran Project Based Learning (PjBL) Terhadap Kemampuan Berpikir Kritis dan Psikomotorik Siswa Pada Pembelajaran Fisika di SMA Negeri 1 Prambanan [Universitas Ahmad Dahlan].

http:/ / eprints.uad.ac.id/15846/

Hardiarti, S. (2017). Etnomatematika: Aplikasi Bangun Datar Segiempat pada Candi Muaro Jambi. Aksioma, 8(2), 99-110. https://doi.org/10.26877/aks.v8i2.1707
Ilham, A. N., \& Sofyan, A. (2012). Tlpologi Bangunan Rumah Tinggal Adat Sunda di Kampung Naga Jawa Barat (Building Typology of Sundanese Traditional Houses at Kampung Naga, West Java). Tesa Arsitektur, Journal of Architectural Discourses, 10(1), 1-8. http://journal.unika.ac.id/index.php/tesa/article/view/9

Jatisunda, M. G., \& Nahdi, D. S. (2019). Peran Mathematical Intuition dalam Pembelajaran Matematika. JUMLAHKU: Jurnal Matematika Ilmiah STKIP Muhammadiyah Kuningan, 5(2), 12-24.

https://doi.org/10.33222/jumlahku.v5i2.587

Jung, C. (2016). Psychological types. Taylor \& Francis.

Karwowski, M. (2008). Giftedness and intuition. Gifted and Talented International, 23(1), 115-124

https://doi.org/10.1080/15332276.2008.11673518

Kusuma, D. A., Dewanto, S. P., Ruchjana, B. N., \& Abdullah, A. S. (2016). The role of ethnomathematics in West Java (a preliminary analysis of case study in Cipatujah). Journal of Physics: Conf. Series, 893. https://doi.org/:10.1088/1742-6596/893/1/012020

Lerman, S. (2014). Encyclopedia of mathematics education. Springer Dordrecht. https://doi.org/10.1007/ 978-94-007-4978-8

Lufityanto, G., Donkin, C., \& Pearson, J. (2016). Measuring intuition: nonconscious emotional information boosts decision accuracy and confidence. Psychological Science, 27(5), 622-634.

Mohajan, H. K. (2018). Qualitative research methodology in social sciences and related subjects. Journal of Economic Development, Environment and People, 7(1), 23-48.

Morris, M. W. (2014). Values as the essence of culture: Foundation or fallacy? Journal of Cross-Cultural Psychology, 45(1), 14-24. https://doi.org/10.1177/0022022113513400

Muhtadi, D. (2017). Sundanese Ethnomathematics: Mathematical Activities in Estimating, Measuring, and Making Patterns. Journal on Mathematics Education, 8(2), 185-198.

https:// doi.org/10.22342/jme.8.2.4055.185-198.

Norenzayan, A., Smith, E. E., Kim, B. J., \& Nisbett, R. E. (2002). Cultural preferences for formal versus intuitive reasoning. Cognitive Science, 26(5), 653-684.

https://doi.org/0.1207/s15516709cog2605_4

Pandiangan, P. (2014). Pengukuran dan Sistem Satuan dalam Fisika.

Pardimin, P. (2018). Etnomatematika Dalam Budaya Masyarakat Yogyakarta. Prosiding Seminar Nasional Pendidikan Matematika Etnomatnesia.

Petitmengin-Peugeot, C. (1999). The intuitive experience. Journal of Consciousness Studies, 6(2-3), 43-77.

Prahmana, R. C. I. (2020). Bahasa Matematis Masyarakat Yogyakarta: Suatu Kajian Etnografi. Jurnal Elemen, 6(2), 277-301. https://doi.org/10.29408/jel.v6i2.2101

Pramudita, K., \& Rosnawati, R. (2019). Exploration of Javanese culture ethnomathematics based on geometry perspective. Journal of Physics: Conference Series, 1200(1), 12002.

https://doi.org/10.1088/1742-6596/1200/1/012002

Pratama, B. M. F., Saputro, D. R. S., \& others. (2019). A study of ethnomatematics on Tulungagung marble craft. Journal of Physics: Conference Series, 1211(1), 12100.

https:// doi.org/10.1088/1742-6596/1211/1/012100

Saputra, M. S. A., \& Satwikasari, A. F. (2019). Kajian Arsitektur Tradisional Sunda Pada Desain Resort. PURWARUPA Jurnal Arsitektur, 3(4), 65-74.

https://jurnal.umj.ac.id/index.php/purwarupa/article/downlo ad/3991/3708 
Sembiring, R. K. (2010). Pendidikan Matematika Realistik Indonesia (PMRI): Perkembangan dan Tantangannya. Journal on Mathematics Education, 1(1), 11-16.

Sembiring, R. K., Hadi, S., \& Dolk, M. (2008). Reforming mathematics learning in Indonesian classrooms through RME. ZDM, 40(6), 927-939.

Sinclair, M. (2010). Misconceptions about intuition. Psychological Inquiry, 21(4), 378-386.

https://doi.org/10.1080/1047840X.2010.523874

Umbara, U., Wahyudin, W., \& Prabawanto, S. (2019). Ethnomatematics: how does cigugur traditional community use palintangan on farming. Journal of Physics: Conference Series, 1265(1), 12025.

https://doi.org/:10.1088/1742-6596/1265/1/012025

Wahyudin, W. (2018). Etnomatematika Dan Pendidikan Matematika Multikultural. Prosiding Seminar Nasional Pendidikan Matematika Etnomatnesia.

Wilder, R. L. (1967). The role of intuition. Science, 156(3775), 605-610. https://doi.org/10.1126/science.156.3775.605 